\title{
GCU
}

Glasgow Caledonian

University

University for the Common Good

\section{Relocating Persia/Iran in the contemporary British tourist imaginary}

Khodadadi, Masood; O'Donnell, Hugh

Published in:

Leisure Studies

DOI:

10.1080/02614367.2017.1353126

Publication date:

2018

Document Version

Author accepted manuscript

Link to publication in ResearchOnline

Citation for published version (Harvard):

Khodadadi, M \& O'Donnell, H 2018, 'Relocating Persia/Iran in the contemporary British tourist imaginary', Leisure Studies, vol. 37, no. 2, pp. 132-145. https://doi.org/10.1080/02614367.2017.1353126

\section{General rights}

Copyright and moral rights for the publications made accessible in the public portal are retained by the authors and/or other copyright owners and it is a condition of accessing publications that users recognise and abide by the legal requirements associated with these rights.

Take down policy

If you believe that this document breaches copyright please view our takedown policy at https://edshare.gcu.ac.uk/id/eprint/5179 for details of how to contact us. 


\title{
Relocating Persia/Iran in the Contemporary British Tourist Imaginary
}

\begin{abstract}
This paper examines the construction of three different Persias in British cultural tourists' accounts of their encounters with Iran and its inhabitants and with its Persian heritage. One - which we call Persia-the-Dead - is materialised in the ancient and monumental, and is at the same time heavily mediated by long-standing discourses of Ancient Persia in British and European culture more generally. A second - which we call Persia-the-Living - is mediated by the same largely Orientalist discourses, but its mobilisation is inflected to include the tourists' reactions to encounters with Iranians themselves. What finally emerges is a version of what we propose to call Persia-the-British, which combines both perspectives within an analysis of how Orientalist representations of Persia are simultaneously reinforced, updated and at least partially refocused in the encounter between the living and the dead.
\end{abstract}

Key words: cultural heritage; cultural tourism; destination image; Iran tourism; Persia; visual analysis

\section{Introduction}

In recounting the time-consuming and intrusive administrative formalities to be completed before entering Iran, one of the British bloggers whose work we include in this study had this to say: 'We were kept waiting for quite some time while the necessary visa checks and hand prints were taken!! Once all was in the clear we were allowed into the world of flying carpets and Aladdin' (blog 43). These two short sentences illustrate not only the significant technical differences between visiting Iran and other (broadly speaking) European countries for a British tourist, but also the strongly contrasting types of experience available at different moments in the trip. While the first phase suggests a security-driven apparatus of surveillance (something now entirely absent for travel within the Schengen group, for example), the second opens onto something literary and even magical. While the first is located in what, for the purposes of this paper, we will call a 
'tourist' frame (see below) with its focus on boundary crossing, the second exudes the more pleasure-oriented, even potentially hedonistic frame of leisure.

In this article we analyse interviews with British cultural tourists to 'Persia' - which they clearly understand to be their actual destination once the administrative hurdles of 'Iran' have been overcome - as well as a number of tourist blogs. Our aim in so doing was to obtain a better understanding of how the individuals concerned came to realise several things. Firstly, that there is more than one Persia available to visit in situ, one static and monumental and one more 'living'. Secondly, that this 'living' Persia brings them into largely unexpected contact with Iranians and their intangible culture; and thirdly, that both of these Persias exist in a complex and changing relationship with inherited notions of the Orient as a product of British/European culture. Notions which these encounters to some extent call into question. We therefore historicise not only the Orient, but also Orientalism itself.

Said's (1978) concept of Orientalism revolves around a number of binaries: not only East/West but also rational/irrational, modern/archaic, dominant/dominated, mind/body and so on. Here we examine a number of other interrelated binaries including tourism/leisure and tangible/intangible heritage - the organisational and discursive frames of Persia and Iran respectively - as well as Iran/Britain, the broader ideological context within which a renewed understanding of Britain's 'place in the world' can be seen to be tentatively emerging. In our case, therefore, we will be dealing with an ancient East which operates simultaneously as a proxy both for historical Western power and for its increasingly embattled modernity. At the same time we show how the power of leisure to facilitate personal encounters in the here-and-now suggests at least the possibility of a reconfigured mutual understanding in the future.

We begin with a discussion of cultural tourism as 'serious leisure' followed by an overview of the notions of tangible and intangible cultural heritage. We then move on to a brief introduction to the historical discourse of 'Persia' in European culture more generally, and British culture in particular, before looking in detail at how it is variously mobilised by visitors to Iran in interviews and tourists' blogs. In so doing we hope not just to address a significant gap in this field in relation to understandings of Iran/Persia, but also to 
provide greater understanding of recent developments in some of the key concepts involved.

\section{Cultural Tourism as 'Serious Leisure'}

A key element of our analysis is that a (relatively informal) 'division of labour' between 'Iran' and 'Persia' can be identified in expressions of the tourist experience whereby Iran is presented as a site of (largely organised) tourism while Persia is experienced in addition a site of leisure. Early academic interest in tourism and leisure tended to view these as distinct areas of research (Moore et al., 1995; Carr, 2002). This notion has, however, been increasingly challenged over the past thirty years or so when academics in the field began to demonstrate an interrelationship between the two (Colton, 1987; Hamilton-Smith, 1987; Mannell and Iso-Ahola, 1987; Ryan, 1994) and showed how concepts developed in one field may be used in the other. Our approach, which incorporates both spoken and written texts provided by cultural tourists visiting Iran, resonates closely with what Stebbins (1996, p. 948) defines as 'cultural tourism as serious leisure'. He sees such tourism as a 'liberal arts hobby within the framework of serious leisure theory ... a genre of special interest tourism based on the search for and participation in new and deep cultural experiences, whether aesthetic, intellectual, emotional, or psychological'. Such tourists are routinely drawn to cultural forms such as museums, galleries, festivals, architecture, historic ruins, artistic performances and heritage sites - in other words to both tangible and intangible heritage. This serious leisure springs from 'the tourist's desire to use a particular geographic area to express or realize an amateur or hobbyist interest. This interest is profound and requires a certain level of skill, knowledge, conditioning, or experience' (Stebbins, 1996, p. 948).

\section{Tangible and Intangible Cultural Heritage}

Persia's material cultural heritage, in particular palaces and mosques, is widely acknowledged by our respondents (below) as the primary trigger in their decision to visit Iran, and as a result feature heavily in the many photographs they provide. But not all heritage is necessarily material, and a growing appreciation among British cultural tourists of Iran's intangible cultural heritage was one of the unexpected findings of this project. 
According to the United Nations Educational, Scientific and Cultural Organization (UNESCO, 2017), Intangible Cultural Heritage (ICH) also concerns 'the practices, representations, expressions, knowledge and skills that belong to communities and are held by specific members'. It is 'not static, but it continually transforms and innovates' (Cominelli and Greffe, 2012, p. 245). Its lack of material form has led some commentators to view ICH as fragile, arguing that its 'inherent flexibility - or, in other words, the "ephemeral" character of ICH - makes it particularly vulnerable to being absorbed by the stereotyped cultural models prevailing at any given time' (Lenzerini, 2011, p. 118). Such a view of ICH seems to us to be unnecessarily gloomy in the specific case of Iran/Persia where it is certainly not experienced by our bloggers and respondents as being under threat. It also appears to offer cultural tourists unexpected resources to reimagine their relationship with a country they in some sense 'discover' for the first time during their visit and in addition to interrogate their own sense of a British 'modernity' which they largely take for granted.

\section{Historical Representations of Persia in British/European Culture}

Until 1935 the country now called Iran was known in the English-speaking world as Persia, a name whose European origins date back the Ancient Greeks. The new name, however, did not simply replace the old. Instead, a new symbiosis emerged whereby each name maintains a different set of meanings and a different identity in relation to the same physical (and political) space: as Baum and O'Gorman rightly argue, 'the name Persia commonly conjures up quite different images to the name Iran' (2010, p. 176). Though no longer extant as a polity, 'Persia' through its material heritage remains very much alive in the British cultural imaginary where it represents a both ontologically and epistemologically different country from Iran. These differences are captured by our concepts of Persia-the-Dead and Persia-the-Living.

One of the earliest European references to 'Persis' is found in The Persians, a play by Greek dramatist Aeschylus (525-456 BCE): this is one of a number of sources from which, from the Renaissance on, the name came, mainly through education systems focused at that time on classical languages and their literatures, into European educated culture in general. 'Persia' in Europe has, therefore, been from the outset a local rather than a Persian 
construct. The appropriation of Persia and its empire by European culture - part of the broader process of colonial appropriation referred to by Said (1978) as 'Orientalism' simultaneously enabled its incorporation into a discourse of imperial heritage whereby knowledge of that part of the world 'passed westwards through a series of filters or lenses that were both linguistic and cultural' (Bartlett, 2014, p. 30). By the sixteenth and seventeenth centuries, 'a period dominated by the Empires of Spain, Persia and the Ottomans ... with which [Queen] Elizabeth [the First] repeatedly put England on friendly terms' (Brotton, 2016, p. 16), European understandings of Persian heritage were well established, and provided the discursive frame within which much later writing and thinking would develop. According to Zarrinjooee:

\footnotetext{
Persia fascinated many European travellers throughout the centuries, mainly English and French travellers. These travellers produced various travel accounts, which ... created [a] body of theory and a social knowledge in which there is a considerable material investment (2006, p. 62).
}

Thus, travel literature played a key role in the construction and circulation of discourses of Persia in European (educated) culture from the late Middle Ages on, constructing it as 'a monarchical, pre-Islamic realm' (Peernajmodin, 2002, p. 46) mostly derived from classical tradition and associated with notions of the imperial and the exotic.

\section{Methodology and Analytical Approach}

While the essentially monumental British/European discursive heritage of Persia remains very much in place today, the complex lived experiences of Iranians themselves have produced a very different relationship with the corresponding intangible heritage that pervades their everyday lives. Below we examine the differing social imaginaries (Taylor, 2004) within which both forms of heritage are received and understood by British cultural tourists when exposed to them in Iran itself.

The philosophical frame we adopted for this project was social constructionist and our approach was inductive and driven by the data gathered, the units of analysis being the various texts generated by the interviews and the internet searches (travel blogs) which 
followed. Our analysis of the data collected is based on the work of a number of theorists, most notably Michel Foucault's thinking on discourse, Edward Said's and Homi Bhabha's work on postcolonialism and, for the visual analysis of the photographs supplied by some of our bloggers, on texts written by Roland Barthes and (to a lesser extent) Pierre Bourdieu.

\section{Data-Gathering Procedures}

The first phase of the study took the form of post-visit semi-structured interviews with British cultural tourists who had visited Iran/Persia in the period 2007-2011. The number of UK tourists visiting Iran during this period was very small (Table 1) hence locating suitable participants proved to be extremely challenging.

[Table 1 here]

Even so ten interviews were eventually conducted between May 2009 and October 2011 in order to establish respondents' understandings of their destination both before and after visiting it. In order to recruit our participants, we prepared a message and posted it on the discussion forum section of some of the most popular travel guide and information websites such as Lonely Planet, Trip Advisor and Travelpod. In total seven potential participants replied to our posts and another three were identified using a snowball sampling technique. Outline demographics of the respondents are provided in Table 2.

[Table 2 here]

Nine of the interviews were conducted via telephone as most of the interviewees were located in different parts of the UK making it impossible to conduct them in person. The remaining interview was conducted face-to-face.

Given the small number of interviews secured, we then turned our attention to travel blogs as complementary sources of data. During the past decade the internet has become an important source of data collection for researchers as it provides a platform where traces of human thought are recorded in ways that were once unimaginable (Bernard and Ryan, 
2010, p. 20). Travel blogs constitute an extremely valuable but so far relatively overlooked resource in this field (Choi et al., 2007; Banyai and Glover, 2012; Bosangit et al., 2015), presenting an attractive source of qualitative data. They provide rich and deep personal accounts, the richness deriving from the longitudinal nature of a blog and the connections the blogger establishes with broader issues. The depth is a result of the freedom in the writer's topic selection (Jones and Alony, 2008). Travel blogs can provide rich insights into how tourists 'express the transformational effects of their experiences for the self' (Bosangit et al., 2015, p. 1). Banyai and Glover (2012, p. 267), for instance, argue that 'blogs offer the opportunity to reveal tourists' interpretations of tourism products and experiences, and to express tourists' impressions, perceptions, thoughts, and feelings' which may not be revealed in a more constrained research environment.

In total fifty-two travel-blog entries posted by twenty British tourists who had visited Iran between 2007 and 2011 were identified and reviewed. These were collected from two of the most popular online travel blogs: www.travelblog.org, founded in April 2002, and www.travelpod.com, which has been in operation since 1997. These sites are referred to as two of the most prominent ones among public travel-blog sites (Bosangit et al., 2009; Banyai and Glover, 2012). Our criteria for the selection of travel-blog entries were primarily based on the nationality of the writers (i.e. British) and the timeframe discussed above.

\section{Visual Analysis}

Photography, leisure and travel are intrinsically linked (Urry, 1990; Urry and Larsen, 2011). Lo et al. (2011, p. 725), for instance, argue that 'photography and mass tourism emerged at around the same time' and photography is now recognised as an integral part of the everyday life of ordinary people. It has therefore been 'crucial in developing the tourist gaze and tourism more generally; they are not separate processes but each derives from and enhances the other, as an "ensemble" (Urry and Larsen, 2011, p. 187). With the development of the internet and Web 2.0 applications, travellers are now able to create their own materials about their leisure/travel (Stepchenkova and Zhan, 2013). Photographs therefore play a fundamental role in helping the tourist construct travel memories and form those memories into complex narratives or stories (Lo et al. 2011, p. 726). Despite 
this, research into the ways in which amateur photography contributes to the construction of tourist discourses remains relatively under-developed in certain areas of leisure and tourism research. As Prochaska points out, although 'the history of photography is an intellectually "hot" subject today in art history and visual culture ... [it] is somewhat less so in colonial and postcolonial studies' (2008, p. 248).

Many of the blogs analysed as part of this research included photographs taken by the tourists themselves. In keeping with our overall approach, we looked at these from a social constructionist perspective, in other words one which strongly opposes claims to 'realism' and focuses on the reality constructed by the images themselves. According to Bourdieu:

only in the name of a naïve realism can one see as realistic a representation of the real which owes its objective appearance not to its agreement with the very reality of things (since this is only ever conveyed through socially conditioned forms of perception) but rather to conformity with rules which define its syntax within its social use (1990, p. 77).

We analysed the photographs using a Foucauldian lens. For Rose (2012, p. 194), 'the Foucauldian understanding of discourse has had a huge impact on studies of visual culture'. She points out (195) that discourse analysis can be used to 'explore how images construct specific views of the social world ... This type of discourse analysis therefore pays careful attention to the image itself'. In this article we analyse how the blog photographs contribute to the visual (re)production of discourses of Persia, and as a result to the social reality of Persia itself. We also paid particular attention to the role of captions. According to Meyrowitz, the impact of a 'representational symbol' such as a photograph derives from the fact that it 'is understood in one act of seeing: it is perceived in a gestalt' (1985, p. 96). However, the lack of linguistic elements which makes this immediate impact possible can also result in the meaning of the image being unclear, or even ambiguous, as a consequence of which 'people often rely on a picture's verbal caption to determine the picture's specific meaning' (98). 


\section{The Amateur Photograph}

The particular visual representations we include all take the form of amateur photographs. For Bourdieu, who has produced an important body of work on amateur photography, the output of the amateur photographer is typically conformist, dominated by what he calls the 'consecration' of a small range of social institutions and experiences. Barthes, on the other hand (2000, pp. 100ff), searches for the punctum, the personally touching and arresting detail which establishes a direct relationship between the viewer and the object viewed. As we will see later, both of these apparently contradictory views of the amateur photograph can be seen to be vindicated in our sample, but in relation to different objects. The conformist photograph relates primarily to representations of Persia-the-Dead constructed around ancient buildings, while the non-conforming photographs taken and displayed by the bloggers, and invariably foregrounding contact with locals who provide the punctum, attempt to demonstrate the existence of an ontologically, or at the very least phenomenologically, different Persia still visibly alive in its intangible heritage.

\section{Foucauldian Discourse Analysis}

The central concept of Foucault's work - in both his (to use his own terms) 'archaeological' and 'genealogical' periods - is that discourses do not in any sense simply describe their objects, they produce them. Discourse is therefore always imbricated with power. As Strydom argues (2000, p. 82), the 'discursive field' is to be understood 'in the sense of the structured context of the constructive activities of collective actors who produce and reproduce reality' (in our case, Persia in its various manifestations as well as Iran). In addition, for Foucault no single text - whether linguistic, visual, musical and so on - or single statement within such a text can on its own constitute a valid unit of analysis. For him discourses and discursive formations are by definition 'systems of dispersion' (1972, p. 41): 'dispersive' because they are spread over numerous sites, and in addition 'systems' because they are not simply spaces of unrestrained creativity but are places where particular constructions of reality are repeatedly reproduced and articulated. Since our quest to map British cultural tourists' experience of Persian heritage dealt with numerous texts originating from different sources and produced within different communicative contexts (blogs and interviews) and we were searching for the regularly 
recurring elements dispersed across this range of texts, such an approach proved particularly productive.

While Foucault's earlier archaeological work concentrated on highly structured and codified centres of power - for example medicine, discipline or education - and their relationship with systems of surveillance and control, his genealogical analyses revealed a much greater interest in the partial and fragmentary nature of power which works through 'its overall decisions and its capillary interventions alike' $(1987$, p. 84). To the extent that power in this sense can be detected in our study, it is not in the fixities of the monumental that it emerges, but in the interstitial spaces of leisure where its highly fragmented, disruptive work arises in the haphazard encounters between visitors and locals rather than largely pre-established routes of the tourists.

\section{Persia-the-Dead: Monumental, Awe-Inspiring and Still}

For both bloggers and interviewees, Persia most frequently emerges as a historical (i.e. now dead) entity associated with a small number of sites such as Yazd, Esfahan, Shiraz and Persepolis - in fact these cities constitute the Standard Tourist Route offered by Iranian tour operators to incoming visitors (see Figure 1):

[Figure 1 here]

On the website of Iranian tour operator AITO, the route shown above is specifically referred to as 'Persian Journey'.

It is also relatively clear from our interviews that it is primarily through education (both formal and informal), literature and film that the tourists' mostly second-hand knowledge of the country has been mediated, a process through which they appropriate Persia as part of their own cultural heritage:

My mother used to buy me children's history books when I was a boy, like Alexander the Great, and I just remember these images, possibly not accurate ones, of fabulously dressed and very elegant Persians and thought wow what a fascinating civilisation that 
must have been, everyone looked great. I had an interest in that part of the world since I was a child and I remember reading the history of Alexander the Great and being more interested in the Persians than the Macedonians ... the truth is I was always intrigued by the place and its history (Interviewee 3).

The question of historical or representational accuracy seems relatively secondary for this interviewee, the focus being instead on the 'fabulous' and the 'intriguing', and the timeframe constructed is an emphatic but only very vaguely defined past, a vagueness which facilitates appropriation.

The question 'What is your opinion of Persia?' produced the following answers where the ancient, the literary, the imperial and the aesthetic combine:

I think ancient and artistic and quite beautiful, that's what I would say in three words. I think when you read up about Persia it's all about the Silk Road and China through to Persia and all this kind of luxury goods and in Persepolis you see these grand statues and what it must have been like then (Interviewee 8).

Of course the name Persia conjures up far more positive, it has a far more positive connotation than like Iran. I think because when people think of Persia they think of gardens, they think of palaces, they think about Imperial history. They think of, well I don't know, Arabian Nights and literature and I think the name has far more positive associations (Interviewee 10).

Interviewee 3 above was unable to suppress a 'wow' in answer to one of our questions, and the bloggers frequently employ a similar lexis of admiration. The specific tourist gaze (Urry and Larsen, 2011) which these sites construct is 'Behold!'. As one blogger put it: 'From Masuleh we went to Isfahan!! WOW what an absolutely beautiful place. I loved it. Stunning and so worth a visit' (blog 2).

The bloggers also draw heavily on a range of historical (the Greek historian Herodotus), more recent (the early twentieth-century British travel writer Robert Byron) and contemporary (the Lonely Planet guide - a standard source for British cultural tourists) 
European cultural referents which construct Persia as a site of the monumental and the universal:

It's a source of great excitement for me to revisit, at least in my mind, the wonderful city of Esfahan. Good ole Lonely Planet describes Esfahan as "Iran's masterpiece, the jewel of ancient Persia and one of the finest cities in the Islamic world." ... And no wonder. There is a 16th century half-rhyme which claims Esfahan nesf-e jahan Esfahan is half the world. Robert Byron was also clearly impressed when he ranked "Isfahan among those rarer places like Athens or Rome, which are the common refreshment of humanity" (blog 24).

I wanted to visit the ruins of Persepolis - the ancient ceremonial capital of Persia that was destroyed by Alexander the Great in 330 BC. I read about Persepolis from the ancient Greek historian Herodotus who recounted strange and lurid tales of Persian, Median and Babylonian kings (blog 5).

Despite the occasional bursts of excitement, however, the photographs expressing the discourse of Persia-the-Dead could just as easily be captioned Persia-the-Still (in the photographic as well as the physical sense), the latter belonging fairly and squarely in Echtner and Prasad's third-world tourism-marketing 'unchanged' category whose main elements are 'Lands of Legend/Past/Significant Silence/Relics' (2003, p. 678). As Urry and Larsen put it:

By erasing contemporary signs, modern humans and connections elsewhere, western travel photography imprisoned the Orient in a timeless ancient space of architecture and monuments to produce the desired authentic Orient (2011, p. 169).

In the words of Althusser (though referring to the Chinese Empire), this Persia 'is somehow stripped of all duration (1972, p. 76). The discourse mobilises, therefore, the eternal and the universal, both hallowed grand narratives of European modernity (Afary and Anderson, 2005, p. 22).

Indeed, were individuals to appear in the foreground they would disturb the historical and never-changing nature of the Persia being constructed here. Both the visual and the 
linguistic discourse construct Persia as a place one gazes on rather than lives in, offering an aesthetic rather than an in any sense convivial experience. They suggest a quasiKantian concept of beauty at work which, as Bourdieu puts it, expresses 'the lived experience of a homo aestheticus who is none other than the subject of aesthetic discourse constituted as the universal subject of aesthetic experience' (1984, p. 495).

\section{Persia-the-Living: the Past in the Present, Intangible Culture and the Human Voice}

In the accounts of the cultural tourists, Persia as Intangible Heritage comes into play when - and only when - interviewees and bloggers recount experiences which bring them in one way or another into direct leisure-time contact with Iranians themselves. The monumental with its tourism focus ceases to be centre stage and the emphasis is invariably on the locals' friendliness and hospitality. There is considerable interest in both traditional and more recent cultural elements such as poetry, fashion and cuisine, while teeming, multi-coloured human warmth and hospitality, and even fun and enjoyment are increasingly to the fore:

\footnotetext{
After spending the first night in Tehran I went on an overnight bus to Shiraz which I found a particularly rewarding place to visit mainly because the people there are so friendly, in fact the hospitality is overwhelming and my friend and I made three separate contacts without really trying, amazingly kind active hospitality and friendship (Interviewee 2).
}

Photographs expressing the discourse of Persia-the-Living are the most personalised of all those appearing in the blogs: they often feature the author him or herself, or a companion, in what are presented to some extent as 'ersatz-family photos'. They are, in Larsen's words, 'less concerned with spectatorship and "consuming places" than with producing ... social roles, and social relationships, such as family life' (Larsen, 2005, p. 417). One tourist can be seen eating food in an Iranian house ${ }^{1}$ - food being a central element of cultural heritage (Brulotte and Di Giovane, 2014). The visual mode of address here is 'Come In!', revealing the 'dialectic of inside and outside' (Bachelard, 1957, p. 211) in a way which is unthinkable for Persia-the-Dead, a place of hard uninhabited space. Yet another image shows tourists surrounded by a group of local schoolgirls ${ }^{2}$ where the captions stress closeness ('local girls'), friendship and camaraderie ('Julia and her crew') 
and breaking down barriers ('meeting strangers in Esfahan'). In contrast to the petrified surfaces of Persia-the-Dead which resist puncture, these photographs exemplify the Barthesian punctum, the unexpected detail which infuses the image with meaning and life, and establishes a quasi-personal relationship between it and the viewer, shown here by the informal language and (relatively) spontaneous nature of the shots. In Larsen's words, 'Most tourist places are "dead" until actors take the stage and enact them: they become alive and transformed each time that new plays begin and face-to-face proximities are established and new objects are drawn in' (2005, p. 422).

Locals encountered by the bloggers are often identified by their names and are seen as the bearers of a still-living heritage which complements, rather than being detached from (i.e. 'outside'), its clear roots in the past: ancient poetry, we discover, is still learned today in Iran as part of the national curriculum (Ministry of Education, 2016), even sung on occasions, and is 'brought to life' through the facilitating and other roles played in it by 'locals':

That evening I met up with Fatima, the girl I'd met in Esfahan, and we got a taxi to the tombs of two famous Persian poets. The first was Hafez (1315-1390) a Persian lyric poet whose collected works (Divan) are to be found in the homes of most Iranians, who learn his poems by heart and use them as proverbs and sayings to this day ... We then took another taxi to the tomb of Sa'di (1184 - 1283/1291?) - a favourite poet of my friend Fatima (blog 5).

Another recounts how his group's guide, Mohsen, likewise sang ancient poetry, something which caused no surprise to passers-by: ${ }^{3}$

We meandered along the river bank to the Paddy Wagon [the tourists' bus] and then set off to the next bridge ... It turned out to be a real cultural visit as Mohsen audibly displayed the acoustics of the bridge design - I can't recall what he sang; perhaps something from Hafez or one of the other esteemed Persian poets. That no one gave Mohsen strange looks as he sang under the arches of the bridge was no accident. Of an evening the locals meet to talk and more importantly sing or recite Hafez or maybe Ferdosi [sic] (blog 25). 
Reference to the palace of Cyrus the Great and a group of (female) students visiting it ${ }^{4}$ gives rise to comment on how Persia can bring together the (very) ancient and the (ultra) modern, the latter here presented as Iranian:

\begin{abstract}
A large group of architect [sic] students were taking note of Cyrus' Private Palace. These young ladies whilst adhering to the Islamic dress code, weren't exactly rigid in said adherence. Their designer sunglasses, makeup, head scarves just about on their heads and figure-hugging manteau ${ }^{5}$ suggested a daring that only Iranians (and not Westerners) would get away with (blog 21).
\end{abstract}

Indeed, fashion and beauty are seen as modern resources which bring together the old and the new via the trope of Persian beauty:

Locals promenading unhurriedly, conservatively dressed older women in full black garb, young women in near Western clothing, hajibs barely on their heads, make up accentuating their Persian beauty (blog 28$){ }^{6}$

And while Persia-the-Dead is dominated by inert, motionless and largely monochrome stone, the organic life of gardens somehow animates Persia-the-Living and, even in the absence of people, they are attributed with a youth-friendly status as 'cool' rather than stately and 'magnificent':

We got to visit a couple of cool Persian Gardens which are extremely beautiful and conform to a strict pattern - they are known as Paradise Gardens (blog 12). ${ }^{7}$

Appreciation, clearly, but hardly 'WOW!!'.

Unlike Persia-the-Dead whose construction as a tourism site can be traced to clearly identifiable institutions - the Iranian state and its official (public and private) tourism promotion institutions and services - it is not possible to isolate clearly demarcated centres of power which can explain the exuberance of Persia-the-Living: there is no central coordination of the haphazard, even accidental tourist encounters with the locals, the unexpected invitations to visit and eat at their houses, the fashion choices of the young women photographed and so on. Foucault's 'genealogical' approach, with its focus on 
'accidents and "minute deviations"' (Afary and Anderson, 2005, p. 22), helps us to understand this 'second-order' dispersion, dispersion within dispersion, interstitial and unpredictable in its emergence. In terms of the tourists' photographs, we are not dealing so much with the 'tourist gaze' - organised, planned for, ready and waiting to be activated within an already existing frame. To borrow a term from television studies, we are dealing more with a 'tourist glance'. This glance responds fitfully to the unforeseeable stimuli of the moment; it is spontaneous but nonetheless does not exist in a discursive vacuum. As we have shown, the Orientalist frame remains, even if now inflected and challenged in its expanded environment.

\section{Persia-the-British: Persia as a Social and Ideological Space}

The representations of Persia and its historical and modern manifestations analysed above are by no means 'innocent' - they are deeply embedded in discourses of power. Aitcheson et al. remind us (2000, p. 23) that Barthes (1982), in Empires of Signs, stressed 'the representation of power and power of representation displayed by monuments, statues, signs and symbols which the modern city offers to the tourist gaze' (he was in fact referring to his own experience of Tokyo). When we look more closely at Persia-theLiving and Persia-the-Dead, we can see that different 'social spaces' like these 'are not simply juxtaposed: they may be intercalated, combined, superimposed - they may even sometimes collide' (Lefebvre, 1991, p. 88). Both Persias in fact overlap since Iran as a political-administrative entity also contributes materially and in many ways - for example through school curricula - to the perpetuation of both the tangible and intangible heritage of Persia which the tourists in their different ways 'enjoy'.

They are both, however, located within a much larger macro-discursive space, a broader 'social imaginary' which we might call 'Persia-the-British' (or more generally 'Persia-theEuropean'), where past and present, tangible and intangible, coalesce. The many references to great figures from Classical (European) antiquity suggest strongly that, for many of the bloggers in particular, Persia is less a historic entity in its own right than, as Orientalism suggests, a metonymic sign of the former greatness of Europe. This now petrified greatness is still visible in the imperial ruins of the past appropriated by the tourists as reminders of the self-ascribed universal and lasting values of a British/European 
sense of self which is now 'ashamed rather than proud of its own imperial past' (Morris, 2012, p. 8). These relics of the past constitute a lingering source of wonder ('wow!') in a post-greatness ‘liquid modernity’ (Bauman, 2000). The tourists are, in Bhabha's words, simultaneously 'pedagogical objects and performative subjects', located 'between a plenitudinous present and the eternal visibility of a past' (1994, p. 151). But while objects can only be beheld, 'gazed at', perhaps even 'learned by rote', the liminality of subjects allows them to perform their own unpredictable, creative, even transgressive subjectivities.

The internal fissures and contradictions of Persia-the-British are particularly clear in the tension between a certain 'post-imperial melancholy' (Pamuk, 2006, p. 122) and the vital and energetic Iran/Iranians of the present (albeit still the Orientalised objects of formal and informal British and European pedagogy). Persia is now simultaneously a celebration of both a continuing British 'past-in-the-present' (Bhabha, 1994, p. 130) and a newly discovered British 'present-in-the-past', a still Orientalised but more self-questioning British self as a result of its unexpected encounter with a welcoming and hospitable but also intriguing, even sexually alluring Iran (the 'gaze' framing some of the images of young Iranian women is clearly a male gaze). As Foucault himself put it during an interview with a Zen Buddhist priest in Japan, 'If a philosophy of the future exists, it must be born outside of Europe or equally born in consequence of meetings and impacts between Europe and non-Europe' (interview reproduced in Carrette, 1999, pp. 110-114). Even so, his Orientalist framing of Iran is, like that of our respondents, displaced rather than fully overcome. As Afary and Anderson argue in their review of Foucault's writings on Iran and the Iranian revolution of 1979:

\footnotetext{
To the extent that there is an Orientalist subject in Foucault's work, it is not a geographical and spatial one, but a philosophical and temporal one, a discourse that moves across the East/West divide ... Foucault's 'East' ... opens up the possibility that pre-rational forms of thought could be mistaken for supra-rational ones $(2005, \mathrm{p}$. 19).
}

The challenges of Orientalism remain, but some of the leisure-seekers in particular seem to sense that an engagement with Persia-the-Living, and the spontaneous encounter with Iranians in their daily lives outside the tourist frame, might offer at least a partial way out 
of some of its inherited aporias. In particular while some sense of a 'pre-rational exotic' is not entirely lost, processes of 'othering' appear to be less self-confident than before.

\section{Conclusion}

Despite UK press coverage of Iran which is at times far from positive (Khodadadi and O’Donnell, 2017), for the adventurous British cultural tourist wishing to visit an exotic Other in relative safety, Iran/Persia seems a good option compared with the 'post 9/11 ... construction of pseudo-colonial states in Iraq and Afghanistan' (Guhin and Wrytzen, 2016, p. 131), not to mention Syria or, increasingly, Turkey. The political rhetoric of Huntington's (1993) 'Clash of Civilisations' seems very far away, particularly when compared with current developments in the United States and elsewhere, and sites of 'world' (i.e. formally 'universal') heritage can be enjoyed in relative peace and safety by visitors and tourists. It is no surprise that the recent reestablishment of diplomatic relations between Iran and the UK has seen spectacular growth in the number of British tourists going there (Press TV, 2016). The links between Persia-the-Dead and museum (and related tourism) practice is very clear, and the associated 'heritage industry' in Iran is relatively well-resourced, but we hope to have shown that there is no simple hermetic dividing line between Persia-the-Living and Persia-the-Dead; in fact we want to align ourselves with an increasing awareness in the field of intangible heritage that ' $\mathrm{t}] \mathrm{he}$ regrettable split between tangible and intangible heritage specialisations should be brought to an end' (Kaufman, 2013, p. 20).

However, while the geographical place where Persia-the-Dead and Persia-the-Living meet is undoubtedly Iran and the discursive space is Persia-the-British, the ideological locus is in our view an embattled British/European modernity attempting to deal with the fall of Empire and the subsequent loss of collective self-assurance. The Classical authors dominating the writings of bloggers and the words of respondents suggest a continuing search for the roots of European modernity in an ancient past as compensation for the increasingly dysfunctional more recent one in terms of its claims to the universal and the eternal. Perhaps Foucault was right at least in that respect: the necessary re-imaginings can only come from outside Europe. 
In response to Bourdieu and Wacquant's (1992) 'invitation to reflexive sociology' (which grew out of Bourdieu's personal experience in Algeria during its period of French colonial rule), we have endeavoured throughout this study to remain aware of the potentially 'Orientalising' effects of this project itself. All our data comes to us via our British interviewees and bloggers and though Iranians at times appear in the photographs shown they are never the authors of these images. The Iranians of today may no longer be Aeschylus's 'barbarians' of yore (Hall, 2015, p. 314), but remain the 'strangers in Esfahan', 'outsiders' even in their own land: they too become, therefore, objects of a potentially Orientalist gaze by proxy. Even Foucault's 'genealogical' approach fails to grasp this nano level of detail. How Iranians live their own day-to-day experiences of Iran (and no doubt less-frequent encounters with Persia) does not emerge from this research. There are glimpses of an Iran which is less regimented and supervised than widespread discourses in the West (including Great Britain) might suggest, and fun, enjoyment and even creative and contestatory approaches to fashion are by no means absent. A future project might usefully examine these elements of Iranians' experience of their own society less centrally filtered through our inevitably Western(ised) gaze. Though always potentially vulnerable to the 'violence of essentialization and epistemic violence' (Guhin and Wrytzen, 2016, p. 126), it might tentatively contribute to a 'reflexive post-orientalist sociology ... more optimistic about the possible uses of positive knowledge' (p. 131).

\section{References}

Afary, J. and Anderson, K.B. (2005). Foucault and the Iranian revolution: gender and the seductions of Islamism. Chicago: University of Chicago Press.

Aitcheson, C., Macleod, N.E. and Shaw, S.S. (2000). Leisure and tourism landscapes. London: Routledge.

AITO (2010). 'Persian Journey'. Azadi International Tourism Organisation. Accessed 03 March 2016. www.aitotours.com/dtour/22/persian-journey/default.aspx

Althusser, L. (1972). Althusser - Rousseau - Marx. London: Verso.

Bachelard, G. (1957). The Poetics of Space. Translated by Maria Jolas. Boston: Beacon Press.

Banyai, M. and Glover, T.D. (2012). Evaluating Research Methods on Travel Blogs. Journal of Travel Research, 51(3): 267-277. 
Barthes, R. (2000). Camera Lucida: Reflections of Photography. Translated by Richard Howard. London: Vintage Books.

Barthes, R. (1982). Empires of Signs. Translated by Richard Howard. New York: Hill and Wang.

Bartlett, R. (2014). Ancient Iran in the Imagination of the Mediaeval West. In A.M. Ansari (Ed.), Perceptions of Iran: History, Myths and Nationalism from Medieval Persia to the Islamic Republic, 37-46. London: I.B. Taurus.

Baum, T.G. and O'Gorman, K.D. (2010). Iran or Persia: What's in a Name, the Decline and Fall of a Tourism Industry? In W. Suntikul and R. Butler (Eds.), Tourism and Political Change, 175-185. Oxford: Goodfellow.

Bauman, Z. (2000). Liquid modernity. London: Polity.

Bernard, H.R. and Ryan, G.W. (2010). Analyzing Qualitative Data. California: Sage Publications.

Bhabha, H.K. (1994). The location of culture. London: Routledge.

Bosangit, C., Hibbert, S. and McCabe, S. (2015). "If I was going to die I should at least be having fun": Travel blogs, meaning and tourist experience. Annals of Tourism Research, 55: 1-14.

Bourdieu, P. (1984). Distinction: a social critique of the judgement of taste. Translated by Richard Nice. London: Routledge.

Bourdieu, P. (1990). Photography: A Middle-brow Art. Translated by Shaun Whiteside. Cambridge: Polity Press.

Bourdieu, P. and Wacquant, L. (1992). An invitation to reflexive sociology. London: Polity Press.

Brotton, J. (2016). This Orient isle: Elizabethan England and the Islamic world. London: Penguin Books.

Brulotte, R.L. and Di Giovine, M.A. (Eds.) (2014). Edible Identities: Food as Cultural Heritage. Vermont: Ashgate Publishing Group.

Carr, N. (2002). The Tourism-Leisure Behavioural Continuum. Annals of Tourism Research, 29(4): 972-986.

Carrette, J.R. (Ed.) (1999). Religion and culture: Michel Foucault. London: Routledge.

Choi, S., Lehto, X.Y. and Morris, A.M. (2007). Destination image representation on the web: Content analysis of Macau travel related websites. Tourism Management, 28: $118-129$. 
Colton, C. (1987). Leisure, Recreation, Tourism: A Symbolic Interactionism View. Annals of Tourism Research, 14: 345-360.

Cominelli, F. and Greffe, X. (2012). Intangible cultural heritage: Safeguarding for creativity. City, Culture and Society, 3(4): 245-250.

Echtner, C.M. and Prasad, P. (2003). The context of third world tourism marketing. Annals of Tourism Research, 30(3): 660-682.

Euromonitor. (2013). Travel and Tourism in Iran Report. Euromonitor International. July 13. Accessed 06 August 2013. https://www.portal.euromonitor.com/

Foucault, M. (1972). The archaeology of knowledge. London: Tavistock.

Foucault, M. (1978). The history of sexuality 1: will to knowledge. London: Penguin.

Giscard, E. and Palin, L. (2008). The social production of heritage through cross-media interaction: making place for place-making. International Journal of Heritage Studies, 14(3): 281-297.

Guhin, J. and Wrytzen, J. (2013). The violences of knowledge: Edward Said, sociology, and post-orientalist reflexivity. In J. Go (Ed.), Postcolonial sociologies: a reader, 113-144. Bingley: Emerald.

Hall, E. (2015). The Ancient Greeks. London: Vintage.

Hamilton-Smith, E. (1987). Four kinds of tourism. Annals of Tourism Research. 14: 322344.

Huntington, S.P. (1993). The clash of civilizations and the remaking of world order. London: Simon and Schuster.

Kaufman, N. (2013). Putting intangible heritage in its place(s): proposals for policy and practice. The International Journal of Intangible Heritage, 8: 19-36.

Khodadadi, M. and O'Donnell, H. (2017). UK press and tourist discourses of Iran: a study in multiple realities. Leisure Studies, 36(1): 53-64.

Larsen, J. (2005). Families Seen Sightseeing. Space and Culture, 8(4): 416-434.

Lefebvre, H. (1991). The Production of Space. Translated by Donald Nicholson-Smith. Oxford: Wiley-Blackwell.

Lenzerini, F. (2011). Intangible Cultural Heritage: The Living Culture of Peoples. The European Journal of International Law, 22(1): 101-120.

Lo, I.S., McKercher, B., Lo, A., Cheung, C. and Law, R. (2011). Tourism and online photography. Tourism Management, 32(4): 725-731. 
Mannell, R. and Iso-Ahola, S. (1987). Psychological Nature of Leisure and Tourism Experience. Annals of Tourism Research, 14: 314-331.

Meyrowitz, J. (1985). No Sense of Place: The Impact of Electronic Media on Social Behavior. New York: Oxford University Press.

Ministry of Education. (2016). National Curriculum, Islamic Republic of Iran: Ministry of Education, Accessed 14 March 2016.

www.medu.ir/portal/home.php?ocode $=100010876$

Moore, K., Cushman, G. and Simmons, D. (1995). Behavioural Conceptualization of Tourism and Leisure. Annals of Tourism Research, 22(1): 67-85.

Morris, J. (2012) Pax Britannica: the climax of an empire. London: Faber and Faber.

Pamuk, O. (2006). Istanbul: memories of a city. London: Faber and Faber.

Peernajmodin, H. (2002). Orientalist Perceptions of Persia in the Works of Spenser, Marlowe, Milton, Moore and Morier. PhD diss., University of Birmingham.

Press TV. 2016. Huge rise of $200 \%$ in UK tour sales to Iran. Accessed 20 September 2016. www.presstv.ir/Detail/2016/09/16/485024/Huge-rise-of-200-in-UK-tour-salesto-Iran-

Prochaska, D. (2008). Telling Photos. In E. Burke III and D. Prochaska (Eds.)

Genealogies of Orientalism: history, theory, politics, 245-285. Lincoln and London: University of Nebraska Press.

Rose, G. (2012). Visual Methodologies: An Introduction to Researching with Visual Materials (3rd ed.). London: Sage.

Ryan, C. (1994). Leisure and tourism: the application of leisure concepts to tourist behavior - a proposed model. In Tourism, the State of the Art, A. Seaton, (Ed.), pp. 294-307. Chichester: Wiley.

Said, E.W. (1978). Orientalism. London: Penguin Books.

Stebbins, R.A. (1996). Cultural Tourism as Serious Leisure. Annals of Tourism Research, 23(4): 948-950.

Stepchenkova, S., and Zhan, F. (2013). Visual destination images of Peru: Comparative content analysis of DMO and user-generated photography. Tourism Management, 36: $590-601$.

Strydom, P. (2000). Discourse and knowledge: the making of enlightenment sociology. Liverpool: Liverpool University Press. 
Taylor, C. (2004). Modern social imaginaries. Durham and London: Duke University Press.

TravelBlog. (2017). About TravelBlog. Accessed 02 February 2017. https://www.travelblog.org/about.html

TravelPod. (2017). About TravelPod. Accessed 02 February 2017. http://www.travelpod.com/

UNESCO. (2017). Intangible Cultural Heritage. United Nations Educational, Scientific and Cultural Organization. Accessed 03 February 2017. http://www.unesco.org/culture/ich/en/what-is-intangible-heritage-00003

Urry, J. (1990). The tourist gaze. London: Sage.

Urry, J. and Larsen, J. (2011). The tourist gaze 3.0. London: Sage.

Zarrinjooee, B. (2006). Travel, Robert Byron and the metamorphosis of self. PhD diss., University of Berlin.

\section{Blogs Cited}

Blog 2: 2010. 'Iran and the floating backpacks...', TravelPod, September 20. Accessed 03 March 2011. http://blog.travelpod.com/travel-blogentries/karen1012/1/1285105927/tpod.html

Blog 5: 2010. 'Shiraz, Persians and Sassanians', TravelBlog, July 22. Accessed 05 March 2011. www.travelblog.org/Middle-East/Iran/South/Shiraz/blog-515174.html Blog 6: 2010. 'Meeting strangers in Esfahan', TravelBlog, July 6. Accessed 03 March 2011. www.travelblog.org/Middle-East/Iran/West/Esfahan/blog-512442.html

Blog 12: 2010. 'A gate 2 tombs 2 gardens a shrine and a castle' TravelPod, September 18.

Accessed 04 March 2011. http://blog.travelpod.com/travel-blogentries/glassmerchant/1/1284817908/tpod.html

Blog 15: 2010. 'Iran', TravelBlog, July 31. Accessed 03 March 2011. www.travelblog.org/Middle-East/Iran/blog-510666.html

Blog 21: 2008. 'Another day, another ruin, another city', TravelPod, November 6.

Accessed 03 March 2011. http://blog.travelpod.com/travel-blogentries/skiwiman/1/1226014080/tpod.html 
Blog 23: 2008. 'Esfahan - half of the world, and a world apart', TravelPod, November 8.

Accessed 03 March 2011. http://blog.travelpod.com/travel-blogentries/skiwiman/1/1226201100/tpod.html

Blog 24: 2008. 'Esfahan nesf-e jahan', TravelPod, November 8. Accessed 03 March 2011. http://blog.travelpod.com/travel-blog-entries/skiwiman/1/1239910140/tpod.html

Blog 25: 2008. 'On foot and home by magic carpet', TravelPod, November 10. Accessed 03 March 2011. http://blog.travelpod.com/travel-blogentries/skiwiman/1/1265284186/tpod.html

Blog 28: 2008. 'Yazd to Esfahan - lest we touch the darkness', TravelPod, November 8.

Accessed 03 March 2011. http://blog.travelpod.com/travel-blogentries/skiwiman/1/1226176140/tpod.html

Blog 29: 2009. 'Discover Iran 2008', TravelBlog, July 22. Accessed 08 March 2011. www.travelblog.org/Middle-East/Iran/North/Kandovan-/blog-420880.html

Blog 43: 2009. 'I Predict A Riot', TravelBlog, June 16. Accessed 10 April 2011. www.travelblog.org/Middle-East/Iran/North/Tehran/blog-412786.html

\footnotetext{
${ }^{1}$ The image in question can be found online: https://www.travelblog.org/Photos/5234802

2 The image in question can be found online: http://www.travelpod.com/travel-blogentries/skiwiman/1/1225942140/tpod.html?pbrowser=/skiwiman/1/1225942140/filename/julia-and-hercrew.jpg

${ }^{3}$ The poets mentioned by this blogger are Abu'1-Qasim Ferdowsi Tusi (940-1020) and Khwāja Shams-udDīn Muhammad Hāfez-e Shīrāzī (1325/26-1389/90).

${ }^{4}$ The image in question can be found online: http://www.travelpod.com/travel-blogentries/skiwiman/1/1226014080/tpod.html?pbrowser=/skiwiman/1/1226014080/filename/architect-studentstake-a-break.jpg

${ }^{5}$ Manteau is a garment worn by Iranian women. It is a long top similar to a trench coat.

${ }^{6}$ The image in question can be found online: https://www.travelblog.org/Photos/5214160

${ }^{7}$ The image in question can be found online: http://www.travelpod.com/travel-blogentries/glassmerchant/1/1284817908/tpod.html?pbrowser=/glassmerchant/1/1284817908/filename/persiangarden-built-as-paradise.jpg\#_
} 